10. Bhambri, R., Bolch, T. and Chaujar, R. K., Frontal recession of Gangotri glacier, Garhwal Himalayas, from 1965 to 2006, measured through high-resolution remote sensing data. Curr. Sci., 2011, 102(3), 489-494.

11. Srivastava, D., Recession of Gangotri glacier, Geol. Surv. India, Spec. Publ., 2004, 80, 21-32.

12. Singh, V. B., Ramanathan, A., Pottakkal, J. G. and Kumar, M., Hydrochemistry of meltwater of the Chaturangi glacier, Garhwal Himalaya, India. Proc. Natl. Acad. Sci., India, 2015, 85(1), 187195.

13. Vohra, C. P., Gangotri glacier, Indian Mountaineer, Indian Mountaineering Foundation, 1988, pp. 51-58.

14. Hall, D. K., Bahr, K. J., Shoener, W., Bindschadler, R. A. and Chien, J. Y. L., Consideration of the errors inherent in mapping historical glacier positions in Austria from the ground and space. Remote Sensing Environ., 2003, 86, 566-577.

15. Thompson, L. G., Brecher, H. H., Thompson, E. M., Hardy, D. R. and Mark, B. G., Glacier loss on Kilimanjaro continues unabated. Proc. Natl. Acad. Sci., USA, 2009, 106(47), 19770-19775.

16. Thayyen, R. J. and Gergan, J. T., Role of glaciers in watershed hydrology: a preliminary study of a Himalayan catchment. Cryosphere, 2010, 4, 115-128.

17. Dumka, R. K., Kotlia, B. S., Miral, M. S., Joshi, L. M., Kumar, K. and Sharma, A. K., First GPS derived recession rate in Milam glacier, higher central Himalaya, India. Int. J. Eng. Sci., 2013, 2, $58-63$.

18. Shangguan, D., Liu, S., Ding, Y., Ding, L., Xu, J. and Li, J., Glacier changes during the last forty years in the Tarim Interior River basin, northwest China. Proc. Natl. Acad. Sci., India, 2009, 19, 727-732.

19. Pan, B. T. et al., Glacier changes from 1966-2009 in the Gongga Mountains, on the south-eastern margin of the Qinghai-Tibetan Plateau and their climatic forcing. Cryosphere, 2012, 6, 1087 1101

20. Bhambri, R., Bolch, T., Chaujar, R. K. and Kulshreshta, S. C., Glacier changes in the Garhwal Himalayas, India 1968-2006 based on remote sensing. J. Glaciol., 2011, 57(203), 543-556.

21. Pratap, B., Dobhal, D. P., Mehta, M. and Bhambri, R., Influence of debris cover and altitude on glacier surface melting: a case study of Dokriani Glacier, central Himalaya, India. Ann. Glaciol., 2015, 56(70), 9-15.

22. Ahmad, N. and Rais, S., Himalayan Glaciers, APH Publishing Corporation, New Delhi, 1999

23. Pandey, A. C., Ghosh, S. and Nathawat, M. S., Evaluating patterns of temporal glacier changes in Greater Himalayan Range, Jammu and Kashmir, India. Geocarto Int., 2011, 26(4), 321-338.

24. Aizen, V., Aizen, E. and Nikitin, S., Glacier regime on the northern slope of the Himalaya (Xixibangma glaciers). Quaternary Int., 2002, 27-39.

25. Kulkarni, A. V., Bahuguna, I. M., Rathore, B. P., Singh, S. K., Randhawa, S. S., Sood, R. K. and Dhar, S., Glacial retreat in Himalaya using Indian Remote Sensing satellite data. Curr. Sci., 2007, 92(1), 69-74.

ACKNOWLEDGEMENTS. We thank the Department of Science and Technology, New Delhi for financial support and the Director, G.B. Pant National Institute of Himalayan Environment and Sustainable Development, Kosi-Katarmal, Almora for providing us the necessary working facilities. We also thank Naveen Joshi, Nikesh Pandey, Jagdish Pandey, Pankaj Kandpal and Mohit Tewari for assistance in the field and laboratory.

Received 21 May 2017; revised accepted 30 October 2018

\section{Analysis of iron ore, iron slag and soils of termite nest from Wui village, Nagaland, India}

\author{
Tiatemjen Tzudir ${ }^{1}$, Tiatoshi Jamir ${ }^{1, *}$ and \\ Sukanya Sharma ${ }^{2}$
}

${ }^{1}$ Department of History and Archaeology, Nagaland University, Kohima Campus, Meriema, Kohima 797 001, India

${ }^{2}$ Department of Humanities and Social Sciences,

Indian Institute of Technology, Guwahati 781 039, India

\begin{abstract}
Analysis of iron slag, iron ore and soils of termite nest traditionally utilized in iron forging was conducted in Wui village, Nagaland, India using various techniques. The present study helps in understanding and identifying various chemical properties/compositions, mineralogical qualities and quantities of iron content along with other oxides from the region.
\end{abstract}

Keywords: Iron ore, haematite, metallographic analysis, slag, termite nest.

EARLY metallurgy is known to have been an intellectual and social activity, wherein technology is the product of complex ideology and careful social negotiations ${ }^{1}$. The significance of iron socially has been demonstrated on a global level. Possibly the earliest use of iron was in the form of ochre pigment. Colourful iron oxides of yellow, red and brown shades have been used throughout history as pigments in art and decorations ${ }^{2}$. According to Schweitzer ${ }^{3}$, metals have been widely used for thousands of years, commencing from the Bronze Age to the Iron Age. The timeline of human civilization is represented on the basis of processing technology and the classification of traditional metals into ferrous and non-ferrous ${ }^{4}$. Archeologically, bronze and iron objects are considered as the most important materials that bear crucial information on the technological and socio-political environments of a past community, a notion previously confirmed by C. J. Thomsen in 1831 through his classification of archaeological objects and further categorization of human societies into Stone, Bronze and Iron Ages $^{5}$. Metal production involves a series of engineering processes vis-à-vis smelting of raw materials from ores, making of alloys and various other thermo-mechanical treatments applied in fabrication in understanding the formation of structures that could be traced only through strict scientific methodologies ${ }^{6}$. The present study helps us understand and identify various chemical properties/ compositions, mineralogical qualities and quantities of iron content along with other oxides that might provide crucial data on early iron technology.

*For correspondence. (e-mail: tiatoshijamir@rediffmail.com) 


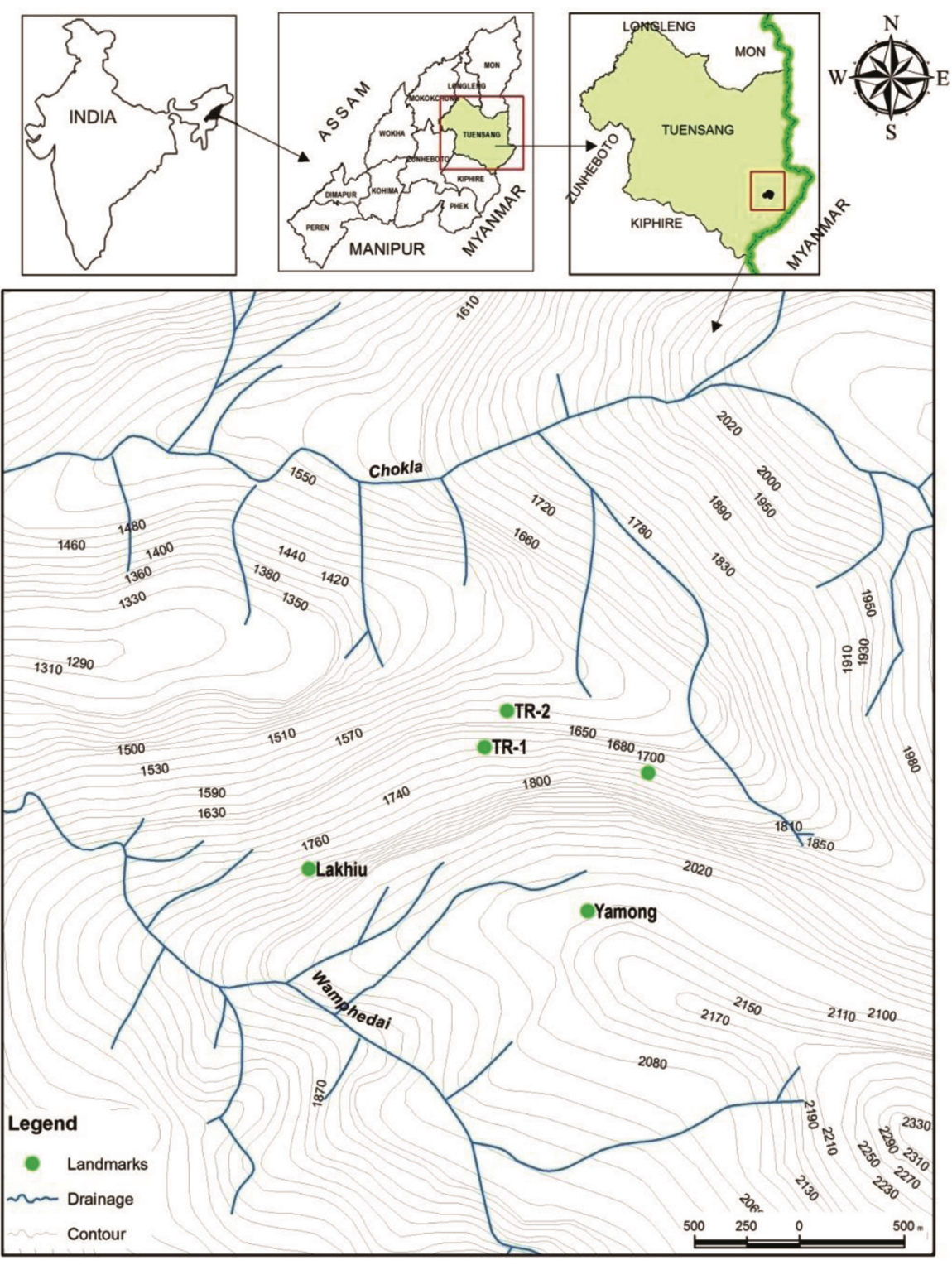

Figure 1. Map of Nagaland showing the location of Wui village and excavated trenches.

Wui is a Khiamnungan Naga village under Thonoknyu administrative circle in Tuensang district, Nagland, India. It lies at lat. $26^{\circ} 02^{\prime} 8^{\prime \prime} \mathrm{N}$ and long. $95^{\circ} 04^{\prime} 16^{\prime \prime} \mathrm{E}$, with an altitude of $1650 \mathrm{~m}$ and is located on the eastern corner of Nagaland close to the Myanmar border (Figure 1). The village is well known for its excellent iron craftsmanship since pre-colonial times (Figure $2 a$ ). At Wui, Chiphur and Chokla section in Tuensang district, tectonized foliated serpentinite is most common ${ }^{7}$. The ultramafic tectonites exposed in Lacham (Phek district) and Wui consist mainly of dunite with minor harburgite and iherzolite ${ }^{8}$. The characteristic assemblages of Naga metamorphics described by Brunnschweiler ${ }^{9}$ are not developed in this part of Naga Hills. However, some isolated outcrops of folded quartz-sericite-chlorite schist and talc-serpentine- chlorite schists were noticed around Chokla west of $1954 \mathrm{~m}$ hills, southeast of Wui and east of Thockchur. Except the last one, all others are present in the eastern part of the ophiolite suite closely associated with ultramafics and volcanics ${ }^{9}$.

Two trenches $(\operatorname{Tr}-1,2 \times 2 \mathrm{~m} ; \operatorname{Tr}-2,1 \times 2 \mathrm{~m})$ were excavated at two different localities of the village, while another large trench was excavated uphill at Malai Dai (MLD; $4 \times 7 \mathrm{~m}$ ), a bog locality. Since people in the area have been engaged in iron-smelting for generations, the probability of retrieving slag refuse from the basal layers of the trenches was high, which would be vital for understanding early metallurgical practice. Tr-1 was laid right above the road section leading to Kingjung village, revealing a thick $4 \mathrm{~m}$ cultural deposit (Figure $2 \mathrm{~b}$ ). Tr-1 


\section{RESEARCH COMMUNICATIONS}
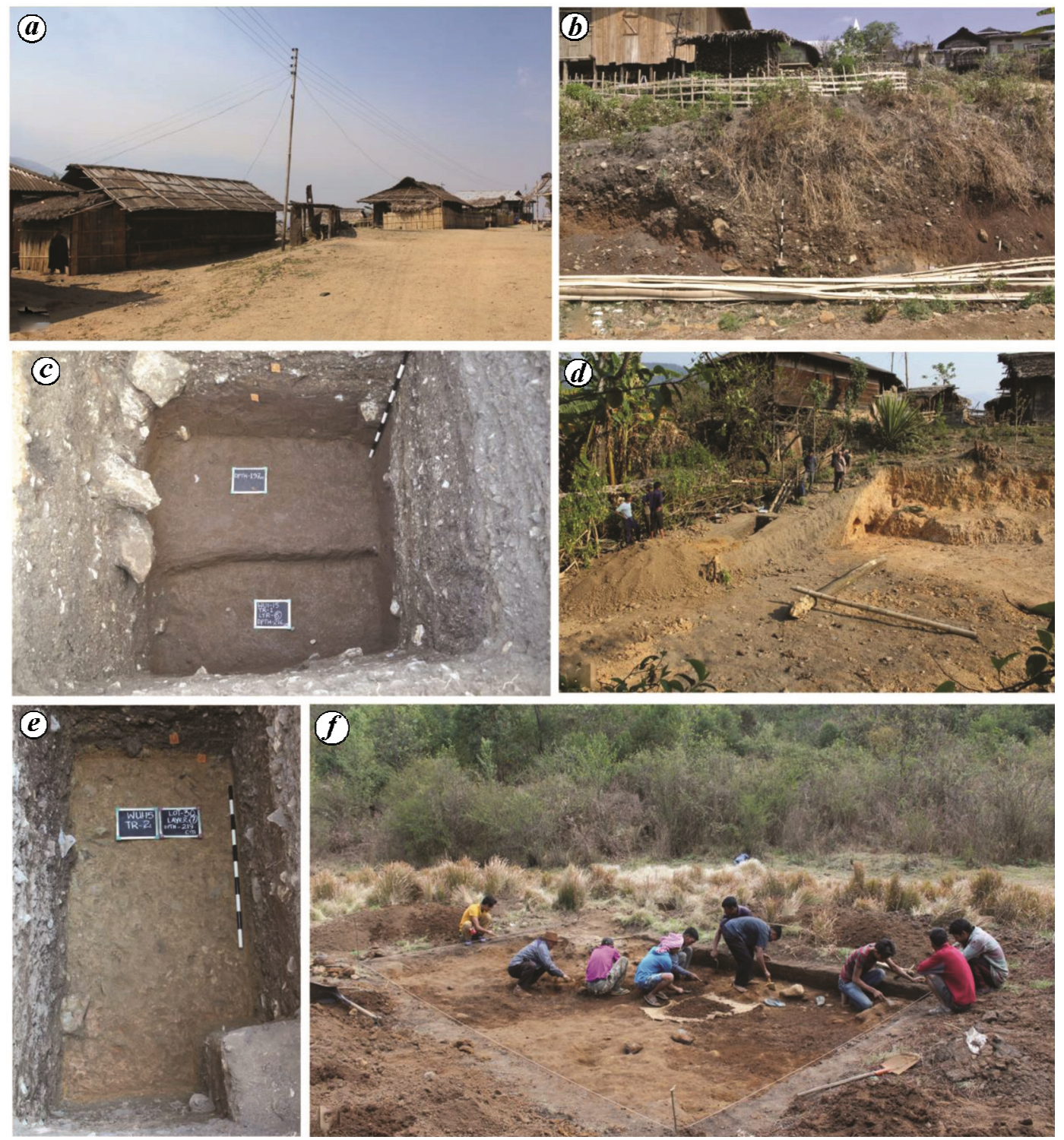

Figure 2. $\boldsymbol{a}$, Partial view of Wui village. $\boldsymbol{b}$, Road section exposing thick cultural deposit where trench-1 (Tr-1) was excavated. $\boldsymbol{c}$, Ground plan view of excavated deposit, Tr-1, layer-6, Depth: $216 \mathrm{~cm}$. $\boldsymbol{d}$, Exposed section of a house site levelling where trench-2 (Tr-2) was excavated. $\boldsymbol{e}$, Ground plan of Tr-2 at depth $219 \mathrm{~cm} . \boldsymbol{f}$, View of bog area at Malai Dai under excavation.

revealed six cultural layers and was excavated to a depth of $216 \mathrm{~cm}$ yielding cord-mark potteries, animal bones, glass beads, slag and good quantity of charcoal (Figure $2 c)$. Tr-2 was laid at Shiu locality by the side of a freshly dug house foundation section revealing a thick habitation deposit (Figure $2 d$ ). Evidence from this trench includes both plain and cord-mark potteries, perforated roof tiles of slates, glass beads and charcoal (Figure $2 e$ ). Soils from both test pits were collected for flotation. Charcoal from the two test pits provided ${ }^{14} \mathrm{C}$ dates that extend to cal BCE 800-753 (Tr-1, layer 6, beta-409506) and cal AD 980-1035 (Tr-2, layer-6, beta-411106) respectively. The trench at Malai Dai bog area above Wui village lies at an elevation of $1721 \mathrm{~m} \quad\left(26^{\circ} 0^{\prime} 02.9^{\prime \prime} \mathrm{N} ; \quad 095^{\circ} 04^{\prime} 28.3^{\prime \prime} \mathrm{E}\right.$;
Figures 1 and $2 f$ ). The deposit containing two layers revealed charcoal, chromite nodules in association with a light brownish soil, partially loose, mixed with fine clayish, and laterite soil along with small gritty stone particles and charcoal ${ }^{10}$.

Microstructural metallographic analysis includes select iron slag and ore samples cut into sizes not less than $2 \mu \mathrm{m}$ and thereafter mounted on a moulded palate (Figure 3). Mounted samples were then polished under electrocoated waterproof silicon carbide abrasive paper ${ }^{11}$ and fitted under the 'double disk polishing machine' to polish the samples. This is further followed by the final polish on a nap velvet cloth to give a scratch-free mirror finish, free from smear, drag or pull-outs and minimal deformation ${ }^{12}$. 


\section{RESEARCH COMMUNICATIONS}

The flat polished surface of material sample for optical microscopy under $25 \times$ magnification was made possible on the iron slag sample from T-2, layer-3 (Figure $4 a$ and $b)$. Rest of the iron slag samples from Tr-1, lot- 8 , layer- 6 , depth 52-69 cm; Tr-2, lot-22, layer-5, depth 147$152.5 \mathrm{~cm}$ and Yamong (Figure $4 c-h$ ) were analysed under powdered form due to their brittle features. The brittle nature is because of their higher level of porosity ${ }^{13}$, and presence of quartz, dolomite, ilmenite, anorthite and tremolite identified through X-ray diffraction (XRD).

XRD analysis on select iron ore and slag samples underwent its initial preparation in order to obtain few tenth

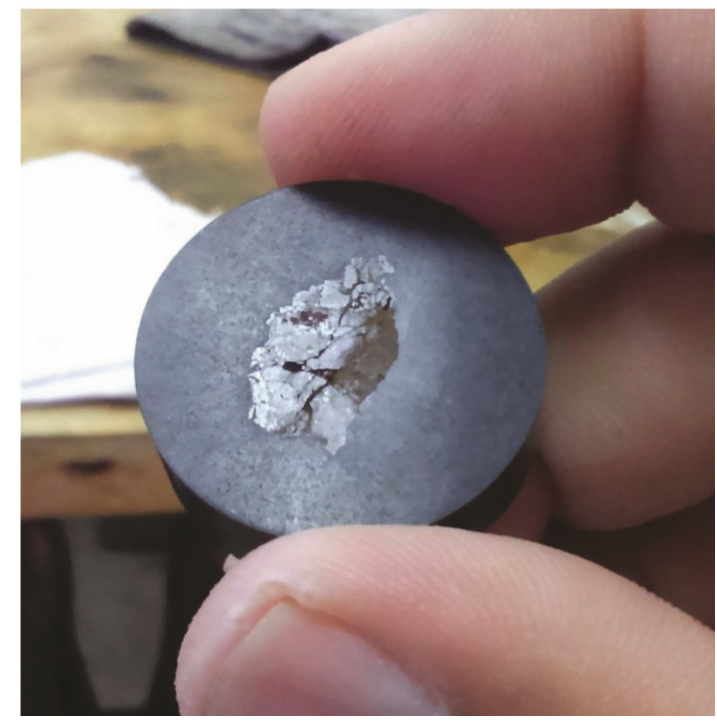

Figure 3. An image depicting the brittle nature of a bog iron slag sample.

Table 1. Trench-1, lot-6, layer-8 - iron slag

\begin{tabular}{lcc}
\hline Mineral group & $D=\lambda / 2 \sin \theta(\AA)$ & Mineral identification \\
\hline Oxides, hydroxides & $4.2475,3.3411$ & Quartz \\
Kaolinites & 4.0627 & Halloysite \\
Feldspars & 2.9277 & Anorthite \\
Oxides, hydroxides & $2.5276,1.4703$ & Haematite \\
Micas & 2.0223 & Biotite \\
\hline
\end{tabular}

Table 2. Trench-1, lot-15, layer-5 - iron slag

\begin{tabular}{lcc}
\hline Mineral group & $D=\lambda / 2 \sin \theta(\AA)$ & Mineral identification \\
\hline Carbonates & 3.8390 & Calcite \\
Oxides, hydroxides & 3.1637 & Rutile \\
Carbonates & 2.8274 & Dolmite \\
Oxides, hydroxides & 2.5576 & Ilmenite \\
Kaolins & $2.3632,1.7425$ & Kaolinite \\
Oxides, hydroxides & $2.1787,1.5406$ & Quartz \\
Micas & 2.0292 & Biotite \\
Oxides, hydroxides & $1.4836,1.4220$, & Haematite \\
& $1.3102,1.2906$ & \\
\hline
\end{tabular}

of gram. The samples were then grounded into fine powder not less than 200 mesh in size as preferred. The samples were then placed in a surface holder, smeared uniformly onto a glass slide and packed inside a sample container there by maintaining a flat surface in order to achieve random distribution of lattice orientations. The results were presented as peak positions at $2 \theta$ and X-ray counts as intensity in the form of a table or an $x-y$ plot (Tables 1-6).

Hardness test is an essential mode of analysing metal samples to understand microstructures in terms of its strength and hardness. There are three principal standard tests for expressing the relationship between hardness and size of impression. Each of these methods is divided into a range of scales as defined by a combination of applied load and indenter geometry. However, select iron slag samples were subjected to micro indenter hardness test $^{13}$ and the Rockwell hardness test collected from Wui, $\operatorname{Tr}-2$, lot-12, layer-3 and from the site of Yamong respectively.

The micro indentation hardness test was performed on iron slag sample obtained from Tr-1, lot-8, layer-6 under $2000 \mathrm{~g}$ indenter load with hardness value of about 161.8 of the slag sample.

Table 3. Trench-2, layer-3 - iron slag

\begin{tabular}{lcc}
\hline Mineral group & $D=\lambda / 2 \sin \theta(\AA)$ & Mineral identification \\
\hline Zeolites & 4.3105 & Sepiolite \\
Kaolins & $3.5719,2.4948,1.7779$ & Kaolinite \\
Feldspars & 2.8283 & Anorthite \\
Oxides, hydroxides & $2.1277,1.5224$ & Quartz \\
Oxides, hydroxides & $1.4439,1.4106,1.2853$, & Haematite \\
& $1.2422,1.1766,1.1509,1.1248$ & \\
\hline
\end{tabular}

Table 4. Yamong - iron slag

\begin{tabular}{lcc}
\hline Mineral group & $D=\lambda / 2 \sin \theta(\AA)$ & Mineral identification \\
\hline Kaolins & 4.0046 & Halloysite \\
Chlorites & 3.5497 & Clinochlore \\
Feldspars & 2.8257 & Anorthite \\
Kaolins & $2.4948,1.6901,1.6239$ & Kaolinite \\
Oxides, hydroxides & $2.1277,1.8595,1.5487$ & Quartz \\
Micas & 2.0367 & Biotite \\
Oxides, hydroxides & $1.7732,1.2980$, & Haematite \\
& $1.2020,1.17102,1.1232$ & \\
\hline
\end{tabular}

Table 5. Soil samples from termite nest

\begin{tabular}{lcc}
\hline Mineral group & $D=\lambda / 2 \sin \theta(\AA)$ & Mineral identification \\
\hline Oxides, hydroxides & $4.2616,3.3513,2.2857$, & Quartz \\
& $1.3736,1.8216,1.5381$ & \\
Oxides, hydroxides & 2.5574 & Ilmenite \\
Oxides, hydroxides & 2.4594 & Goethite \\
Oxides, hydroxides & 1.6711 & Haematite \\
\hline
\end{tabular}


RESEARCH COMMUNICATIONS

Table 6. Malai Dai - iron ore

\begin{tabular}{lcc}
\hline Mineral group & $D=\lambda / 2 \sin \theta(\AA)$ & Mineral identification \\
\hline Kaolins & $7.0379,1.8208,1.7182,1.6628,1.6251$ & Kaolinite \\
Micas & $5.0561,3.3785,2.0367$ & Muscovite \\
Oxides, hydroxides & $4.2475,2.2839,2.1764,1.54117$ & Quartz \\
Mica & $3.3785,2.0367$ & Biotite \\
Amphiboles & 3.1370 & Tremolite \\
Oxides, hydroxides & 2.4535 & Goethite \\
Oxides, hydroxides & $1.1069,1.2881,1.2532,1.1863,1.1527$ & Haematite \\
\hline
\end{tabular}

Table 7. Yamong-iron slag (Rockwell hardness test)

\begin{tabular}{ccccccc}
\hline Scale & Indenter & Load & Minor load & Major load & Total load & Value \\
\hline & & & F0 & F1 & & \\
B & $1 / 16$ ball & $100 \mathrm{kgf}$ & $10 \mathrm{kgf}$ & $90 \mathrm{kgf}$ & $100 \mathrm{kgf}$ & 98 \\
\hline
\end{tabular}

kgf, kilogram force.
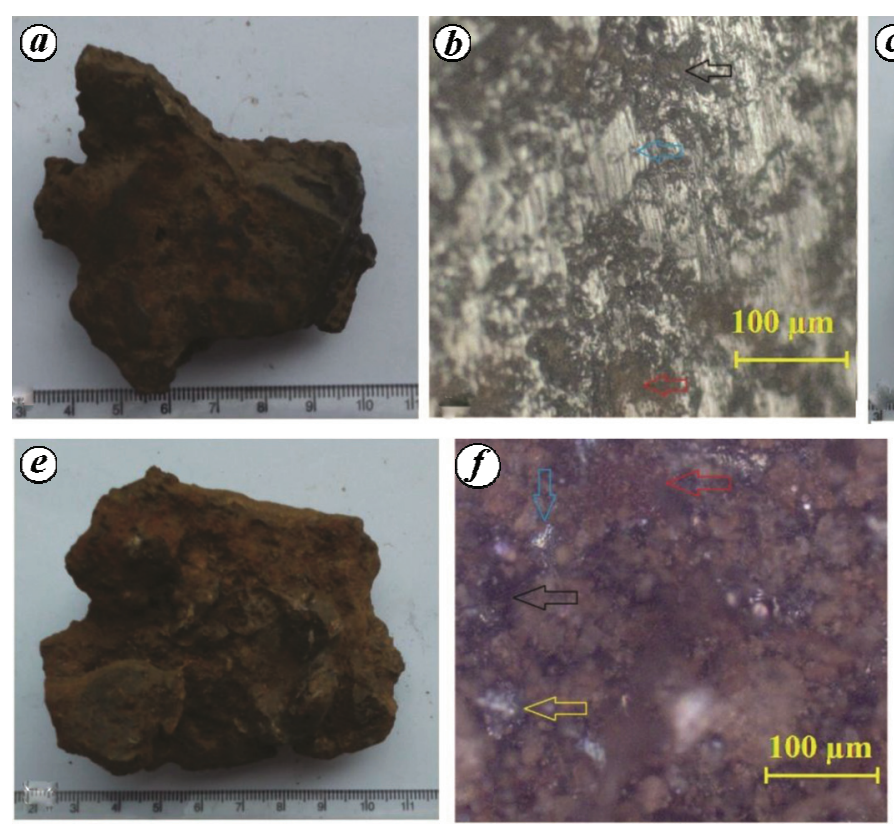
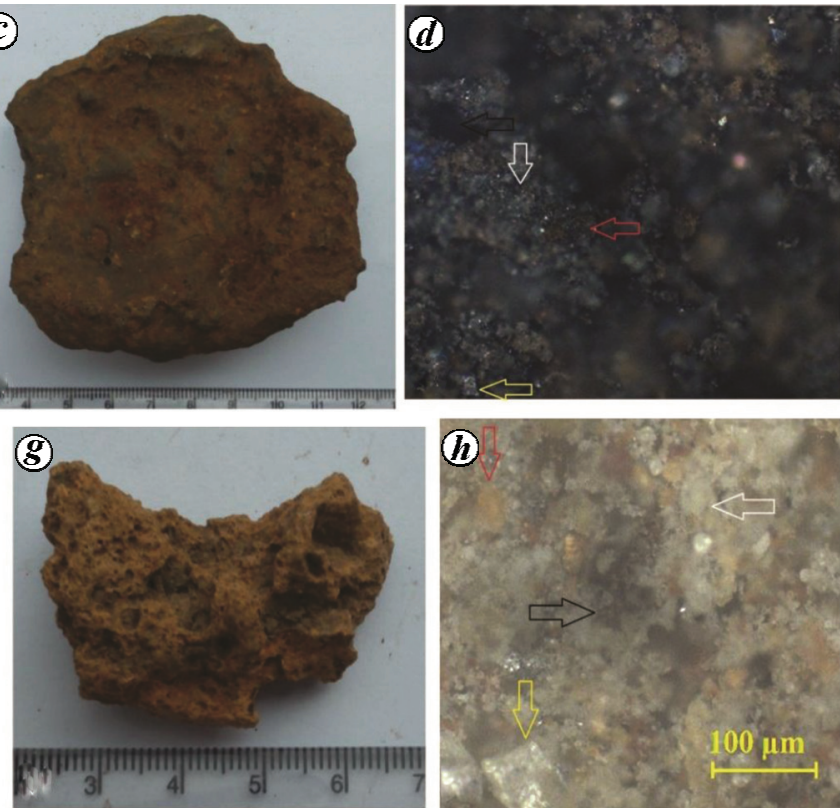

Figure 4. $\boldsymbol{a}$, Iron slag sample from Tr-2, layer-3. $\boldsymbol{b}$, Photomicrograph of a polished sample prepared (Tr-2, layer-3). (Arrows: black-carbon, blueiron metal, red-rustic soil.) $\boldsymbol{c}$, Iron slag sample from Yamong. $\boldsymbol{d}$, Photomicrograph of powdered iron slag (Yamong). (Arrows: black-carbon, white-quartz, red-rustic soil, yellow-iron oxide.) $\boldsymbol{e}$, Iron slag sample from Tr-1, layer-6. $\boldsymbol{f}$, Photomicrograph of powdered form (Tr-1, layer-6). (Arrows: blue-iron metal, black-carbon, yellow-iron oxide, red-rustic soil.) $\boldsymbol{g}$, Iron slag from Tr-2, layer-5. $\boldsymbol{h}$, Photomicrograph of powered sample (Tr-2, layer-5). (Arrows: red-rustic soil, white-quartz, black-carbon, yellow-iron oxide.)

The Rockwell hardness test was performed on a polished iron slag sample from Yamong, using the method of indenting the test material with a diamond cone or hardened steel ball indenter that was forced into the sample material under a load of $100 \mathrm{kgf}$ at ' $\mathrm{B}$ ' scale with 1/16 intender ball, which gave a hardness value of about 98.6. The test proceeded in two steps. At first the penetration start point zero was determined under preliminary load and the second step was done under the major load. Since the sample material was soft in nature, $1 / 16$ identer ball was used with a $100 \mathrm{~kg}$ load, where the hardness was read on the ' $\mathrm{B}$ ' scale (Table 7).
The electrical furnace test was done on the iron ore sample from Malai Dai, to examine its chemical variation. Experiment under the furnace test underwent two trials within a specific temperature of about $160^{\circ} \mathrm{C}$ to a cooling point of about $100^{\circ} \mathrm{C}$ as the first trial step. This was again followed by a second stage of furnace under higher temperature of about $1200^{\circ} \mathrm{C}$ to a similar cooling point of about $100^{\circ} \mathrm{C}$. The selected ore samples had an average size of about $1 \times 2.5 \mathrm{~cm}$ to $3.6 \times 3.6 \mathrm{~cm}$ (Figure $5 \mathrm{a}$ ), and were put inside a ceramic container for the test.

The field emission scanning electron microscope (FESEM) analysis was done on the prepared powdered 


\section{RESEARCH COMMUNICATIONS}
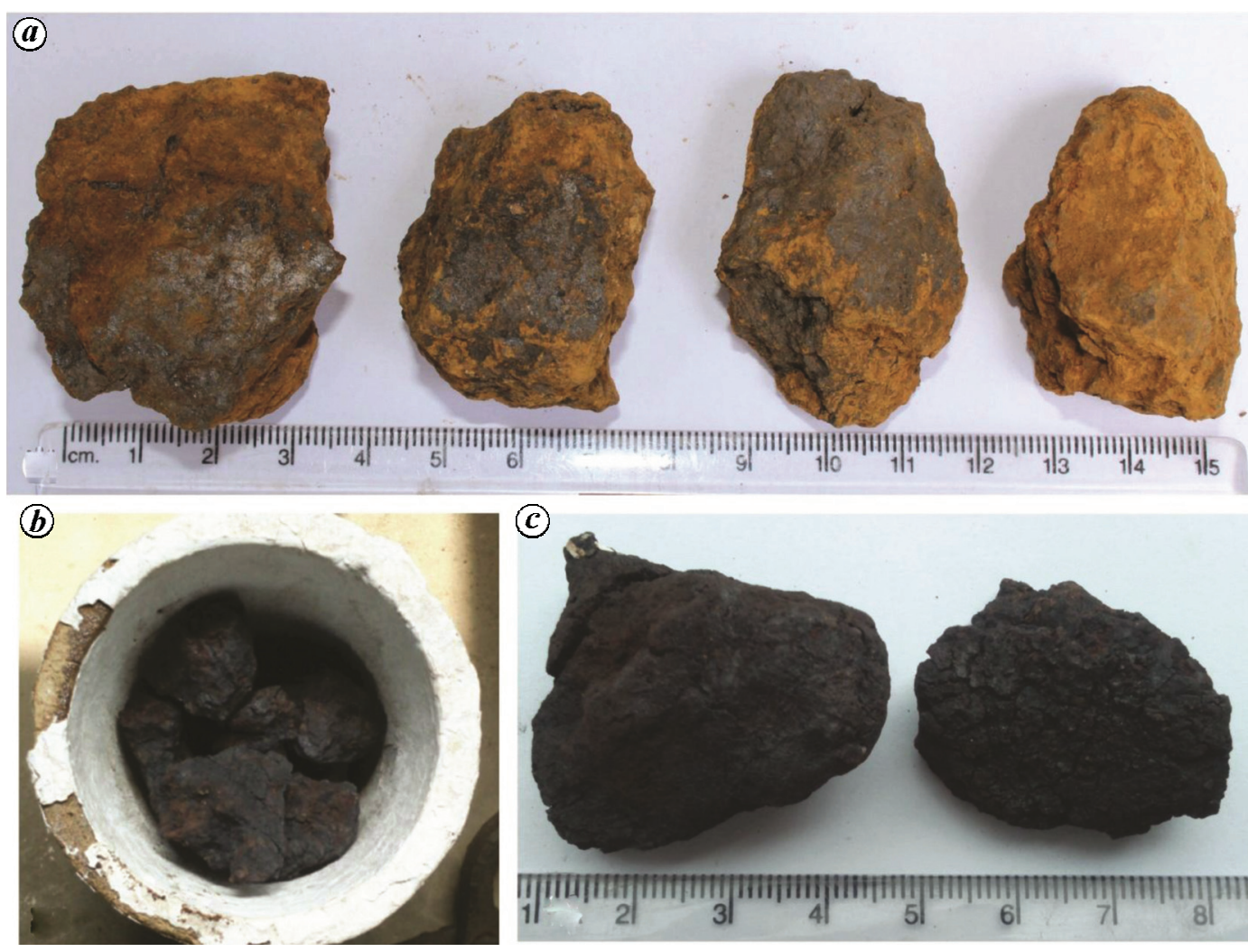

Figure 5. $\boldsymbol{a}$, Material samples of bog iron ore from Malai Dai. $\boldsymbol{b}$, Textural changes in iron ore (Malai Dai) in a furnace at $160^{\circ} \mathrm{C}$. c, Textural changes in iron ore from Malai Dai in a furnace at $1200^{\circ} \mathrm{C}$.

iron slag sample of Tr-2, lot-12, layer-3, depth 70.15$80.15 \mathrm{~cm}$. The powdered sample was mounted on a mounting stub glued by double-sided carbon tape and were micrographed into six photo images under six level of magnified resolution (Figure 6).

The photomicrograph of iron slag sample from Tr-2, layer-3 shows nodular structures indicating iron content with surrounding black patches as signs of carbon and dark brown patches as rustic minerals due to the presence of kaolinite, sepiolite and anorthite in the form of iron oxide, identifying the iron ore as haematite (Figure $4 a$ and $b$ ). Rest of the samples also indicate similar traits (Figure $4 c-h$ ).

The diffraction graphs of iron slag samples from Tr-1, Tr-2, Yamong and iron ore sample from Malai Dai all indicate similar presence of haematite and quartz. Quartz was found in all the samples in the form of muscovite, clinochlore, sepiolite and anorthite. Slag samples from Tr-1, layer-5; Tr-2, layer-3, Yamong as well as iron ore sample from Malai Dai indicate the presence of iron in the form of oxides, as in kaolinite identified through optical microscopy. The iron content is also marked by the presence of rutile, ilmenite, dolomite, clinochlore, tremolite and goethite (Tables 2, 4-6; Figure $7 b, d, e-g$ ). The coarse, brittle, and silicate nature of the select sample is due to the presence of anorthite, quartz, dolomite, ilmenite and tremolite (Figure 3). The differences in colours in the samples such as yellow, darkish brown, black and grey (Figure $6 a-c$ ) are due to the resulting presence of quartz, dolomite, ilmenite, anorthite, sepiolite, clinochlore, muscovite, calcite, rutile and tremolite (Tables 1-6; Figure $7 a-f$ ).

Metal concentration in termite mounds might depend on the chemical speciation of metals in the soil solution ${ }^{14}$. However, soil sample from the termite nest (Lawam) from Wui (Table 5, Figure $7 e$ ) also indicates the presence of goethite as one form of hydraulic mineral which is usually found along with silicate minerals like quartz.

The hardness value received from the select iron slag sample from Tr-1, layer-5 despite the coarse nature of the sample is due to the presence of calcite, dolomite, ilmenite, rutile and haematite where each of these mineral possessed iron oxide with hardness value under the Moh scale. Similarly, in the case of slag sample from Yamong site subjected to Rockwell test has presence of minerals such as haematite and anorthite receiving a value of 98 .

Two different stages of temperatures were made through the electrical furnace test on iron ore samples that provided differing results with the intial first stage of transition in their colours, from yellowish (Figure $5 a$ ) to dark brownish colour (Figure $5 b$ ), indicating the presence of goethite and muscovite with additional patches of deep reddish colour marked by shiny metallic lines of 

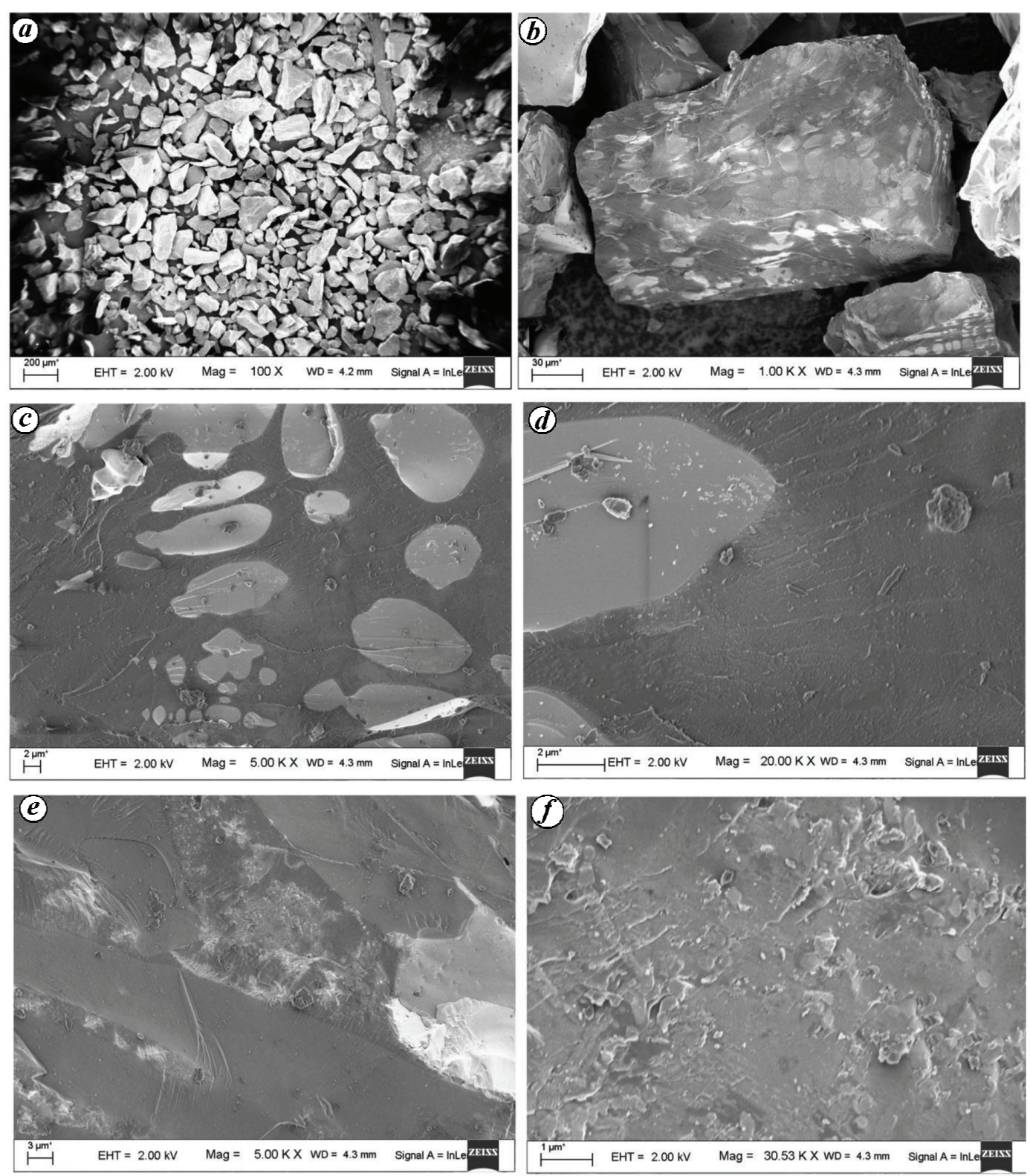

Figure 6. Iron slag samples from $\mathrm{Tr}-2$ under different magnifications. $\boldsymbol{a}, 100 \times ; \boldsymbol{b}, 1.00 \mathrm{KX} ; \boldsymbol{c}, 5.00 \mathrm{KX} ; \boldsymbol{d}, 20.00 \mathrm{KX} ; \boldsymbol{e}, 5.00 \mathrm{KX}$; $f, 30.53 \mathrm{KX}$. KX, Kilovolts under X range control of magnified mode.

iron metal ${ }^{15}$. Along with differentiation in colours, the textures of the ore samples also yielded signs of brittleness due to the presence of silicate minerals such as quartz, biotite and tremolite.

However, the iron ore samples previously tested under $160^{\circ} \mathrm{C}$ were again tested under $1200^{\circ} \mathrm{C}$ to the same cooling point of $100^{\circ} \mathrm{C}$ and yielded similar results in terms of colour but differences in texture resulting towards a more harder state. The differing results in its physical textures from soft and brittle to a more hardened state indicates the undertaking of a partial smelting stage and an outcome of largely oxidised state. This is due to the presence of oxygen having high level of porosity that usually reacts with carbon ${ }^{16}$.
There is also the need of ideal room temperature usually required for a delicate bog iron ore to smelt where melting point of haematite usually takes place under $1565^{\circ} \mathrm{C}$. The resulting factors that led to the metal formation visible in low quantity through the marked linings of shiny metals in between the reddish cherry colored ore (Figure $5 c$ ) thus identifies the presence of kaolinite in the form of rust hue, as well as goethite in higher contents of iron oxide and haematite.

The results from field emission scanning electron microscope (FESEM) done on the prepared powdered iron slag sample from Tr-2; lot-12, layer-3, depth 70.15$80.15 \mathrm{~cm}$ under $200 \mu \mathrm{m}$, EHT $=2.00 \mathrm{kV}$, magnification $=$ $100 \times, \mathrm{WD}=4.2 \mathrm{~mm}$ (Figure $6 a$ ) as its first stage of 
(a)
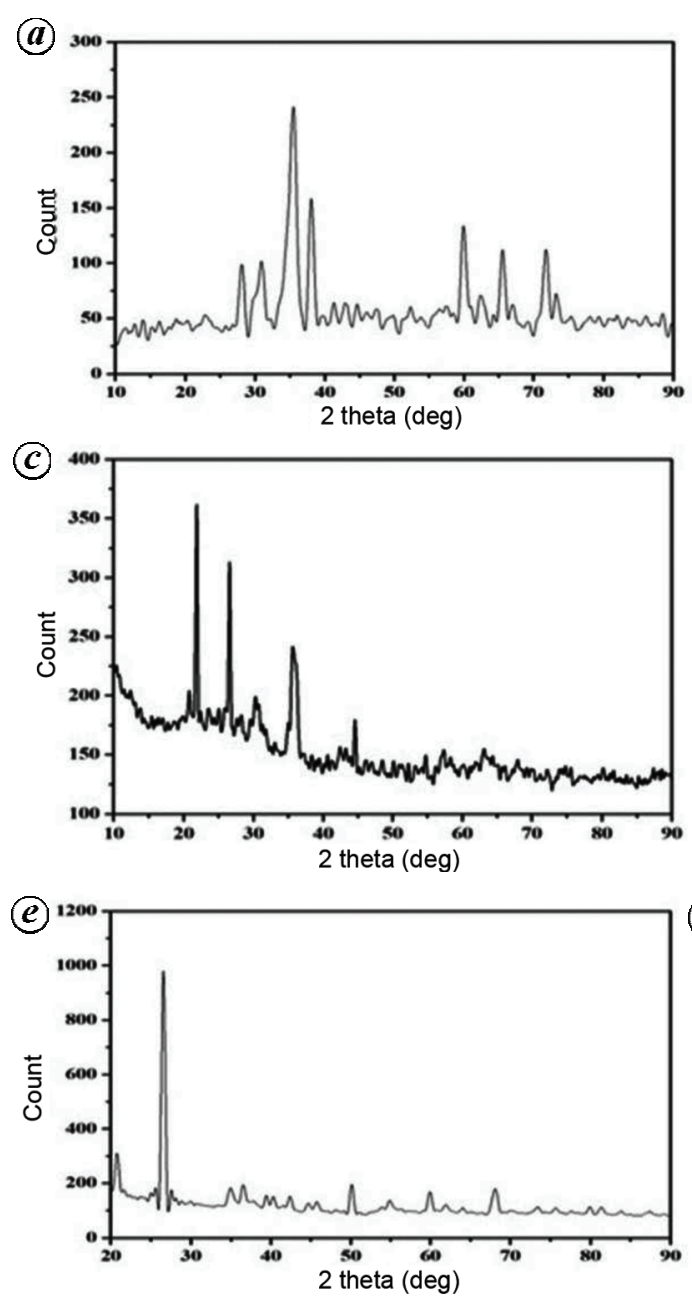
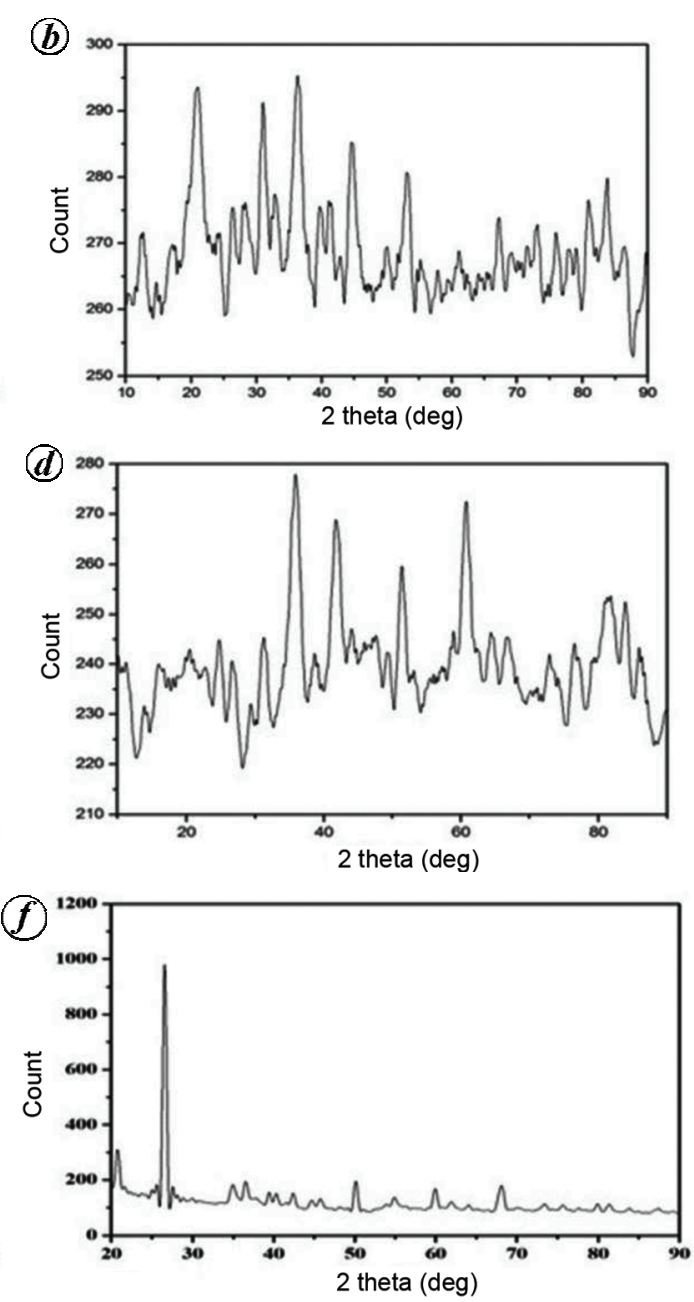

Figure 7. XRD of tested samples (a) Tr-1, layer-8 - iron slag; (b) Malai Dai - iron ore; (c) Tr-1, layer-5 - iron slag; $(d), T r-2$, layer-3 - iron slag; $(\boldsymbol{e})$, Termite nest soil and $(\boldsymbol{f})$ Yamong-Iron slag (surface collection).

analysis yielded in the form of coarse grain mainly due to the presence of haematite visible between the intergranular spaces when observed under $30 \mu \mathrm{m}$, EHT $=$ $2.00 \mathrm{KV}$, magnification $=1.00 \mathrm{KX}, \mathrm{WD}=4.3 \mathrm{~mm}($ Figure $6 \mathrm{~b}$ ). It also indicated the slag appearing bigger and in single-out grain with the presence of iron in the form of nodular shapes surrounded by low carbon content. Furthermore, analysis under $2 \mu \mathrm{m}, \mathrm{EHT}=2.00 \mathrm{KV}$, magnification $=20.00 \mathrm{KX}, \mathrm{WD}=4.3 \mathrm{~mm} \quad$ (Figure $6 c$ ) gave better visibility of iron content surrounded by carbonated mineral due to the presence of dolomite. Under $3 \mu \mathrm{m}$ $\mathrm{EHT}=2.00 \mathrm{KV}$, magnification $=5.00 \mathrm{KX}, \mathrm{WD}=4.3 \mathrm{~mm}$ (Figure $6 d$ ) there is better visibility on further confirmation on the iron content and the carbonated area indicating areas that are coarse. Lastly, the magnified carbonated area of iron slag sample under $1 \mu \mathrm{m}, \mathrm{EHT}=$ $2.00 \mathrm{kV}$, magnification $=30.53 \mathrm{KX}, \mathrm{WD}=4.3 \mathrm{~mm}$ (Figure $6 e$ ) and under $1 \mu \mathrm{m}$, EHT $=2.00 \mathrm{kV}$, magnification $=$ $30.53 \mathrm{KX}, \mathrm{WD}=4.3 \mathrm{~mm}$ (Figures $6 f$ ) reveal coarse texture with visible pores due to the entrapment of oxygen that escaped during cooling and solidification process.
The porous structure (porous ferritic iron), coarser textures, silicate minerals and presence of haematite thus help in identifying the samples as bog iron ore.

Wui village was once known to have produced iron, but it appears to have abandoned the same since ages only to be recounted in the oral tradition of the village. Microstructure analysis, optical microscopy, FESEM, hardness value and XRD have provided a detailed account on the presence of different mineral compositions in understanding the particular type of mineral ore utilized. Such results have been further strengthened using electrical furnace tests performed on carefully selected iron ore samples from Malai Dai site. Furthermore, the archaeologically recovered slag samples from Tr-1, Tr-2 and the slag from Yamong provide identical results, thus indicating probable source of local bog ore. The present preliminary study is part of an ongoing research and further evidence for smelting and iron smithing might be sought for better understanding the technological and social processes involved in pre-modern iron production at Wui and other sites in Nagaland. 
1. Killick, S. C., Indgenious African metallurgy: nature and culture. Annu. Rev. Anthropol., 1993, 22, 317-337.

2. Henshilwood, C. S., d'Errico, F. and Watts, I., Engraved ochres form the middle Stone Age levels at Blombos cave, South Africa. J. Hum. Evol., 2009, 57, 27-47.

3. Schweitzer, P. A., Metallic Materials - Physical, Mechanical and Corrision Properties, Marcel Dekker, New York, USA, 2003.

4. Stalics, A., Metallurgy Made in and for Europe-The Perspective of Producers and End-Users Roadmap, Luxmbourg Publication Office of the European Union, Brussels, 2014.

5. Cunliffe, B., Iron Age Communities in Britian, Routledge Tylor and Francis, Great Britian, UK, 1974.

6. Pollard, A. M. and Brothwell, D. R., Archaeological Sciences, John Wiley, USA, 2001.

7. Vidyadharan, K. T. and Joshi, A., Systematic geological mapping in the Northeasternmos part of Naga Hills ophiolite belt around Chokla-Wui-Kenjong-Chipur-Pang areas, Teunsang district, Nagaland, Geological Survey of India Progress Report (1982-83), 1983.

8. Roy, R. K., Meso-Cenozoic Accretionary Prims on the Margin of Indo-Burman Range Ophiolite and its Implications, Suran Publication, Patna, 1989.

9. Brunnschweiler, R. O., On the geology of Indo-Burman ranges. J. Geol. Soc. Aust., 1966, 13(1), 137-194.

10. Jamir, T., The Ethnography and Archaeology of the Naga Metal Workers: A Case Study on Early Metal Production at Wui Village, Tuensang District (Excavation Report), North East Zone Cultural Centre, Dimapur, Nagaland, 2015.

11. Balasubramaniam, P. D., Characterization of ancient Indian iron and entrapped slag inclusions using electron, photon and nuclear microprobes. Bull. Mater. Sci., 2001, 24, 317-322.

12. Venkannah, S., Metallurgy Lab: Materials Science Module-Mech 2121, Faculty of Engineering, Mechanical and Production Engineering Department, University of Mauritius, 2004; http:// docplayer.net/27437059-Metallurgy-lab-materials-science-mech2121-university-of-mauritius-faculty-of-engineering-mechanicaland-production-engineering-department.html

13. Levi, E. E., Welding advicers.com, 2003; http://www.weldingadvicers.com/

14. Reddy, L. S., Termite mound as an effective geochemical tool in mineral exploration: a study from chromite mining area Karnataka, India. Res. J. Chem. Sci., 2014, V, 85-88.

15. Digges, T. G., Metal laboratory heat treatment, 2012; http://www. metalabheattreat.com

16. Dutta, S. K., Studies on direct reduced iron melting in induction furnace. Trans. Indian Inst. Met., 2004, 57, 467-473.

ACKNOWLEDGEMENTS. Tiatemjen Tzudir thank S.S. for the Internship programme of scientific analysis on Ancient Ceramics; Dr Kanagraj, Department of Mechanical Engineering, IIT Guwahati for providing laboratory facilities; Dr Sachin D. Kore, Department of Mechanical Engineering, IIT Guwahati for guidance; Saiffuddin Ahmed, Rituraj Saikia and the IITG Central Instrument Facility, Charan, Avinish Tiwari, Bikash Kumar, Dr Pankaj Singh, Preyanka and Jeetendra for the support extended.

Received 30 May 2018; revised accepted 4 October 2018

doi: $10.18520 / \mathrm{cs} / \mathrm{v} 116 / \mathrm{i} 2 / 311-319$

\section{A comparison of blood biochemical parameters as a tool to measure welfare in free-ranging red deer (Cervus elaphus elaphus) after chemical and physical restraint}

\author{
Chiara Mariti ${ }^{1}$, Francesca Iacobelli ${ }^{1}$, Eva Ricci ${ }^{1}$, \\ Marco Fusi ${ }^{2}$, Manuel Mengoli ${ }^{3}$, \\ Alessandro Cozzi $^{3}$ and Angelo Gazzano ${ }^{1, *}$ \\ ${ }^{1}$ Dipartimento di Scienze Veterinarie-Università di Pisa, Italy \\ ${ }^{2}$ DEFeNS-Università di Milano, Italy \\ ${ }^{3}$ IRSEA, Institut de Recherche en Sémiochimie et Ethologie Appliquée, \\ Apt, France
}

Eighteen red deer were captured in box traps and then physically restrained in an immobilizing box; three red deer were captured twice, once by chemical restraint (anesthetized with a mixture of Xylazine, Tiletamine and Zolazepam) and once in the immobilizing box. It was found that microhaematocrit, total erythrocyte and leukocyte counts, as well as plasma cortisol, were higher after the physical restraint. Anserine and 3-methyl-L-histidine concentrations were higher after the physical restraint in animals undergoing both captures. Data supports previous studies indicating that the physical restraint after capture is more stressful than the chemical one. Anserine and 3-methyl-L-histidine were higher after the physical restraint in red deer undergoing both methods, suggesting that measuring plasma aminoacyl-imidazole dipeptides and their components may be important in stressed animals prone to capture myopathy.

Keywords: Aminoacyl-imidazole dipeptides, anesthesia, animal welfare, red deer, restraint, stress.

NOWADAYS control and stewardship of deer populations is a complex social, economic, political and biological issue. When free-ranging red deer are overabundant, as occurs in some areas of Italy, their number is usually controlled. Live capture may be more socially acceptable or practical than hunting or sharp-shooting in restricted areas $^{1}$.

The capture and immobilization of wild ungulates, carried out to monitor, treat and move animals, are likely to be stressful events for these animals ${ }^{2}$. This is clearly indicated by behavioural evaluations, sudden deaths, as well as changes induced in various haematological and biochemical blood constituents ${ }^{3,4}$. However, these changes differ considerably according to the methods of capture and restraint used ${ }^{2}$. A remarkable difference in concentration of blood constituents is observed when comparing physical and chemical capture methods ${ }^{5-8}$. The physical

*For correspondence. (e-mail: angelo.gazzano@unipi.it) 